\title{
DEVELOPMENT FEATURES OF STUDENTS' FUNCTIONAL LITERACY THROUGH TEXTS IN FOREIGN LANGUAGE LESSONS
}

\author{
Assel Tabuldina ${ }^{1}$, Zhanar Eskazinova ${ }^{2}$ \\ ${ }^{1}$ Astana International University, Nur-Sultan, Kazakhstan \\ ${ }^{2}$ E.A.Buketov Karaganda University, Karaganda, Kazakhstan
}

ORCID ID: 0000-0001-8307-9014

\begin{abstract}
The growing role of foreign language linguistic competence and especially foreign language functional literacy of a specialist requires a revision of the theoretical foundations and approaches to teaching writing in English in a modern university. This article defends the thesis that the development of linguistic competence through the prism of translation competence plays an important role in the development of foreign language functional literacy. The presented work clarifies the concept of foreign language functional literacy of students through the prism of translation competence and foreign language linguistic competence; recommendations are offered for the further development of a model for the formation of functional literacy in the process of teaching a foreign language in a non-linguistic university.
\end{abstract}

\section{INTRODUCTION}

The modern world has become much more complex than it was twenty, and even more so thirty years ago. These difficulties require a special approach in pedagogy: this is due to the emergence of new technologies, new professions, areas of the economy, and the socio-psychological changes of the person himself. The world around us is no longer analogous-textual, it was replaced by visual-digital - and this requires expansion and rethinking of the concept of "functional literacy".

According to Cavallaro \& Sembiante, functional literacy is the ability of a person to use the knowledge acquired during his life to solve a wide range of life tasks in various spheres of human activity, communication and social relations [Cavallaro, C. J., \& Sembiante, S. F., 2021]. Nowadays, society and the economy make a request for such specialists who want and can master new knowledge, apply it to new circumstances and solve emerging problems, that is, there is a demand for functionally competent specialists. Functional literacy today has become the most important indicator of social well-being, and functional literacy of schoolchildren is an important indicator of the quality of education. The requirements for mastering the elements of subject content are still in focus, but purely academic knowledge is no longer enough.

At present, the attention of the educational community is drawn to the problem of the formation of research competencies and functional literacy of Kazakhstan students, graduate students, young scientists. The leading place in solving this problem is occupied by the issue of the formation and development of functional literacy and taking into account the growing role of the English language as a tool of scientific communication.

According to foreign researchers, written speech is a central component of functional literacy. Therefore, in a modern university, in the process of teaching English, more and more attention is paid to teaching writing, creating scientific and professional texts, as well as teaching educational writing in the framework of some disciplines taught in English. The teaching of writing in English is traditionally carried out within the framework of the "Foreign Language" discipline or specialized courses in academic writing. Subject specialists are also paying more and more attention to teaching writing [De Oliveira, L. C., \& Westerlund, R., 2021].

The concept of "functional literacy" is new for the domestic education system. In this regard, an active discussion of this concept and the need for purposeful education of functional literacy, 
foreign language functional literacy and teaching academic writing began on the pages of Kazakhstans' journals [Shaimardanova, M., Akhmetova, L., \& Nikishina, S., 2020].

The development of a model for the formation and development of foreign language functional literacy is problematic without clarifying the structure of this concept from the point of view of the foreign language component of this concept. The structure of functional literacy from the point of view of the native language is considered in detail in the study by Adil, Percia T., Princess H. Policarpio, and Cavin F. Pamintuan in 2020. At the same time, the issue of proficiency in a foreign language, which is necessary for the free functioning of scientists in the world scientific arena, is not touched upon. Izzah L. \& Hadi M. S. (2021) examine the structure of functional literacy from the point of view of communicative, cognitive and social practices and propose an approach to the formation of functional literacy through the translation of academic written discourse, omitting the features of the formation and development of foreign language linguistic competence in students.

The approach to the development of functional literacy proposed by Cavallaro C. J. \& Sembiante S. F. (2021) is implemented with third-year undergraduate students of the Faculty of Sociology, but the level of development of linguistic competence at the stage of admission to a university, the level of development of linguistic competence among students during the first two years of study, when teaching academic writing is not indicated. not conducted. According to Troyan \& Sembiante (2020), in 2011, at the National Research University Higher School of Economics, during the round table "Academic writing at a modern university: the status of discipline and teaching principles", it was noted that the development of academic skills (the ability to put forward and substantiate one's own ideas, understand and interpret the ideas of others) is given special importance in the educational systems of developed countries [Morton, T., 2020]. At the same time, in Kazakhstan education, there is still no training system aimed at developing academic skills, including in a foreign language.

The processes of globalization and computerization of modern society and scientific knowledge have given modern scientists endless opportunities to promote scientific developments at the international level [Troyan, F. J., \& Sembiante, S. F., 2020]. However, not every article written in English will be accepted for publication in a foreign scientific journal. There are many reasons for this: students and graduate students, and sometimes teachers, do not know how to structure the text as a whole, do not have the skills of argumentation, do not know the style of scientific writing, the level of spoken and professionally oriented English, the level of foreign language functional literacy (competence) Kazakhstans' authors is extremely low. The situation is aggravated by the low level of academic mobility, the lack of experience in participating in international scientific research and publishing articles in foreign publications, and the lack of special courses on the methodology of preparing academic texts.

It should be noted that teaching English in Russia has long been focused, as a rule, on grammar and oral communication in the field of informal communication. Meanwhile, for more than 20 years, English for Specific Purposes (ESP) has been taught in the world, the main focus of which is English for academic and professional purposes. Publishing publications in a foreign language requires not only a high level of functional literacy in the native and foreign languages but also a sufficient level of development of linguistic and translation competencies.

In this regard, the importance of foreign language competence increases in the composition of the professional competence of both scientific and pedagogical workers of the university and future young scientists. In this regard, we consider it necessary to clarify the structure of foreign language functional literacy from the point of view of linguistic competence in order to develop a more accurate model of its formation and development in the process of teaching a foreign language in a nonlinguistic university. As we mentioned earlier in the article, the ability to work with information and create written texts is recognized as the main component of functional literacy. It is important to clarify the structure of foreign language competence required to create texts of different scientific genres in a foreign language. The process of writing a text in English as a foreign language includes the processes of translation activities (perceptual and productive). Typically, scholars (for whom English is not their first language) working in various fields of science create academic texts in their 
native (Kazakh) language and then translate them into English [Shaimardanova, M., Akhmetova, L., \& Nikishina, S., 2020].

According to Morton (2020), in order for students to reach a certain level of translation competence, the level of their linguistic competence must reach at least the upper-middle level (level B2) in accordance with the Common European Framework of Reference for Languages. If measured in points on international exams aimed at determining the level of proficiency in a foreign language, then this will correspond to the following points: International English Language Testing System (IELTS) - 5.5 - 6.5 [Kani, N. B.,2020]; Test of English as a Foreign Language (TOEFL) - 100 [Lee, S., Kuo, L. J., Xu, Z., \& Hu, X., 2020].; First Certificate in English (FCE) - A or B. Along with teaching translation [Llinares, A., \& McCabe, A., 2020], students should be able to further improve their linguistic competence.

The relationship between linguistic and translation competence has rarely been examined by researchers. Before the introduction of the communicative method of teaching a foreign language, translation was considered a method of teaching a foreign language. After the introduction of the communicative method of teaching a foreign language, translation was used only in training programs for translators and interpreters [Ukume, G. D., Uguma, V. U., \& Agbinya, G. A., 2020]. In this paper, linguistic competence refers to the knowledge and ability of learners to use the formal resources of the language to create well-structured and meaningful messages.

There is an opinion that linguistic competence is not enough for practical and educational purposes, we are interested not only in the fact that someone knows the language, but also that someone knows how to use it. Language teaching should contribute to the development of the skill of using language forms by students "in situations close to the context of real life." The concept of communicative competence was introduced, which was later viewed through the prism of studying and teaching a second/foreign language. The following components were distinguished in the structure of communicative competence: grammatical competence (phonology, vocabulary, syntax, semantics); discursive competence (knowledge of the sociocultural rules of language use); sociolinguistic competence (rules of discourse: agreement and coherence of sentences); strategic competence (the ability to overcome difficulties encountered in the communication process). Nevertheless, the issue of integrating these components of communicative competence into the process of learning a foreign language caused many questions and difficulties.

In order to provide the basis for the creation of curricula, foreign language training programs, exams, foreign language textbooks throughout Europe, the Common European Framework of Reference (CERF) was introduced in 2001. Here is the classification of the competencies offered by CERF:

1. General competences [De Oliveira, L. C., \& Westerlund, R., 2021]:

- Declarative knowledge

- Knowledge of the world

- Linguistic and communicative awareness Existential competence

- General phonetic awareness and skills

- Ability to learn

- Learning skills

- Intercultural skills and abilities

- Heuristic skills

- Practical skills and abilities

- Intercultural awareness

- Skills and abilities (know-how)

- Sociocultural knowledge

2. Communicative and linguistic competencies [Izzah, L., \& Hadi, M. S., 2021]:

- Linguistic competence

- Spelling competencies 
- Lexical competencies

- Orthoepic competence

- Grammar competencies

- Sociolinguistic competences

- Semantic competencies

- Courtesy standards

- Phonological competence

- Expression of folk wisdom

- Pragmatic competence

- Use of uppercase and lowercase letters

- Discursive competence

- Functional competence

By considering the concept of translation competence. Among the small number of studies devoted to the development of translation competence, the model proposed by Troyan \& Sembiante (2020) should be mentioned.

It has the following structure:

1. Deep knowledge of both the native language and the language of the translated text [Troyan, F. J., \& Sembiante, S. F., 2020].

2. Knowledge of the native culture and culture of the translated text [Ukume, G. D., Uguma, V. U., \& Agbinya, G. A., 2020].

3. Knowledge of neologisms, nuances and modern changes in the language [Morton, T., 2020].

4. Constant practice of translation [Kani, N. B., 2020].

5. Ability to translate in more than one area of expertise.

6. Fluency in written and spoken language, the ability to quickly and clearly formulate ideas in written and oral forms [Izzah, L., \& Hadi, M. S., 2021].

7. Good translation speed.

8. Development of research skills, the ability to find the reference sources needed to create a highquality translation [Lee, S., Kuo, L. J., Xu, Z., \& Hu, X., 2020].

9. Awareness of the latest technological innovations.

10. Ability to distinguish the geographical features of the language.

\section{CONCLUSION}

It is necessary to note textual competence - the ability to produce translated texts with the structural features of a formal written (English) language. Evaluation factors are nominalization, word length, passive voice, prepositional phrases, etc. Semantic, discursive, pragmatic and cultural competencies are important. Other components of translation competence are in synthesis with each other and include:

- knowledge of the subject area (economics, finance, medicine, etc.);

- computer literacy (operating systems, Windows, Internet);

- the ability to self-check (self-control) - awareness of quality the translation made;

- research competence (ability to use bibliographic and lexicographic sources).

As demonstrated in this article, the role and meaning of translation should be redefined in foreign language lessons. In the process of language learning, it is necessary, simultaneously with the development of foreign language functional literacy, to develop the translation competence of students, which includes all components related to the process of language learning [Llinares, A., \& McCabe, A., 2020]:

- linguistic competence (phonetics, morphology, syntax, semantics, discourse);

- sociolinguistic competence;

- pragmatic competence; 
- intercultural competence;

- competencies directly related to translation activities.

\section{REFERENCES:}

Adil, Percia T., Princess H. Policarpio, and Cavin F. Pamintuan. "A communicative analysis of language functions in the Chinese as a Foreign Language (CFL) textbooks: the case of Happy Chinese." Universal Journal of Educational Research 8, no. 8 (2020): 3725-3733. DOI: 10.13189/ujer.2020.080853

Cavallaro, C. J., \& Sembiante, S. F. (2021). Facilitating culturally sustaining, functional literacy practices in a middle school ESOL reading program: a design-based research study. Language and Education, 35(2), 160-179. https://doi.org/10.1080/09500782.2020.1775244

De Oliveira, L. C., \& Westerlund, R. (2021). A functional approach to language development for dual language learners. Journal of English Learner Education, 12(1), 2. https://stars.library.ucf.edu/jele/vol12/iss 1/2

Izzah, L., \& Hadi, M. S. (2021). Systemic Functional Genre on Students' Reading Literacy. English Language in Focus (ELIF), 1(1), 35-44. https://doi.org/10.24853/elif.1.1.35-44

Kani, N. B. (2020). INFLUENCE OF FUNCTIONAL LITERACY ON EDUCATION. Kazakhstan Science Journal, 3(7 (20)), 9-9. https://sciencejournal.press/sj/article/view/194

Lee, S., Kuo, L. J., Xu, Z., \& Hu, X. (2020). The effects of technology-integrated classroom instruction on K-12 English language learners' literacy development: a meta-analysis. Computer Assisted Language Learning, 1-32. https://doi.org/10.1080/09588221.2020.1774612

Llinares, A., \& McCabe, A. (2020). Systemic functional linguistics: the perfect match for content and language integrated learning. International Journal of Bilingual Education and Bilingualism, 16. https://doi.org/10.1080/13670050.2019.1635985

Morton, T. (2020). Cognitive discourse functions: A bridge between content, literacy and language for teaching and assessment in CLIL. CLIL. Journal of Innovation and Research in Plurilingual and Pluricultural Education, 3(1), 7-17. https://doi.org/10.5565/rev/clil.33

Shaimardanova, M., Akhmetova, L., \& Nikishina, S. (2020). Socialization of foreign university students through the formation of reading literacy. Journal of Social Studies Education Research, 11(1), 42-63. https://www.learntechlib.org/p/216431/

Troyan, F. J., \& Sembiante, S. F. (2020). Developing a Critical Functional Linguistic Knowledge Base for World Language Teachers. In Genre in World Language Education (pp. 32-61). Routledge. https://www.taylorfrancis.com/chapters/edit/10.4324/9780429321009-3/developingcritical-functional-linguistic-knowledge-base-world-language-teachers-francis-john-troyansabrina-sembiante

Ukume, G. D., Uguma, V. U., \& Agbinya, G. A. (2020). Functional literacy in reading comprehension: relative effectiveness of using interactive video instructional mode and tutorial video instructional mode in teaching. Lwati: A Journal of Contemporary Research, 17(1), 18-31. https://www.ajol.info/index.php/lwati/article/view/192061 